\title{
IMPROVING CRITICAL THINKING ABILITY AND MATHEMATICAL DISPOSITION OF HIGH SCHOOL STUDENTS THROUGH INTEGRATED SAINTIFIC APPROACH TO BRAIN BASED LEARNING
}

\author{
Enen Nurbaeti ${ }^{1}$, Meida Sugiharti ${ }^{2}$, Rippi Maya ${ }^{3}$ \\ ${ }^{1,2}$ Graduate Student of Mathematics Education, IKIP Siliwangi, Cimahi, Indonesia \\ ${ }^{3}$ Mathematics Education, IKIP Siliwangi, Cimahi, Indonesia \\ 1. syifanurbaeti92@gmail.com, ${ }^{2}$ meidasugiharti@gmail.com, ${ }^{3}$ rippimaya@gmail.com
}

Received: Jul 12 ${ }^{\text {th }}, 2019 ;$ Accepted: Sept $19^{\text {th }}, 2019$

\begin{abstract}
The purpose of this study was to examine the problem of achievement and improved critical thinking skills and dispositions mathematical high school students between those who use the scientific approach to integrating brain based learning with a scientific approach , examining the association between variablesand an overview of student performance. This study is an experimental study with a design pretest-posttest design. Sampling in this study using purposive sampling technique. The instruments used were tests and non-tests, the test instruments included tests of mathematical critical thinking skills while the non-test included attitude scale tests Student mathematical disposition. The results showed that the achievement and improvement of critical thinking skills (CTS) with a scientific approach to integrating Brain-based Learning (SAIBBL) better than class with scientific approach (SA). Mathematical Disposition (MD) student in the classroom with using learning (SAIBBL) better than students in class with SA. There is a strong association between CTS and MD. The overall picture of student performance with SAIBBL is superior and students are more active in learning. These results prove that the use of SAIBBL is better than SA.
\end{abstract}

Keywords: Critical Thinking Skills, Mathematical Disposition, Scientific Approach to Integrating Brain Based Learning.

\begin{abstract}
Abstrak
Tujuan dari penelitian ini adalah untuk menguji masalah prestasi dan meningkatkan keterampilan berpikir kritis dan disposisi siswa SMA matematika antara mereka yang menggunakan pendekatan ilmiah untuk mengintegrasikan pembelajaran berbasis otak dengan pendekatan ilmiah, memeriksa hubungan antara variabel dan gambaran kinerja siswa. Penelitian ini merupakan penelitian eksperimental dengan desain pretes-postes. Pengambilan sampel dalam penelitian ini menggunakan teknik purposive sampling. Instrumen yang digunakan adalah tes dan non-tes, instrumen tes termasuk tes keterampilan berpikir kritis matematis sedangkan non-tes termasuk tes skala sikap disposisi matematika siswa. Hasil penelitian menunjukkan bahwa pencapaian dan peningkatan Keterampilan Berpikir Kritis (KBK) dengan pendekatan ilmiah untuk mengintegrasikan Pembelajaran Berbasis Otak (PBO) lebih baik daripada kelas dengan Pendekatan Ilmiah (PI). Siswa Disposisi Matematika (DM) di kelas dengan menggunakan pembelajaran (PBO) lebih baik daripada siswa di kelas dengan SA. Ada hubungan yang kuat antara KBK dan DM. Gambaran keseluruhan kinerja siswa dengan PBO lebih unggul dan siswa lebih aktif dalam belajar. Hasil ini membuktikan bahwa penggunaan PBO lebih baik daripada PI.
\end{abstract}

Kata Kunci: Keterampilan Berpikir Kritis, Disposisi Matematika, Pendekatan Ilmiah untuk Mengintegrasikan Pembelajaran Berbasis Otak 
How to Cite: Nubaeti, E., Sugiharti, M., \& Maya, R. (2019). Improving Critical Thinking Ability and Mathematical Disposition of High School Students Through Integrated Saintific Approach to Brain Baseed Learning. JIML, 2 (3), 112-120.

\section{INTRODUCTION}

Mathematics is the subject on a school where a student not only can solve a problem, but they also need high-level thinking. One of these capabilities is the ability to think critically mathematics. Students' critical thinking skills need to be improved, so that students are not only able to deal with mathematical problems at school only, but also able to deal with problems with confidence and have a variety of alternative solutions mastered instead of complaining and feeling unable to follow the mathematics learning process that he carried out so as not to have the motivation to produce positive things and make the results he gets worse .

According to O'daffer and Theonquist and Miller (Senjayawati, 2018) states that the critical thinking skills of middle school students are not satisfactory and they tend to avoid nonroutine questions. This explains that students' low critical thinking skills greatly influence the learning of mathematics. Mathematical disposition can also make someone easier and feel more able to work on the math problems they face, even more complex or specific math problems (Nurjaman \& Sari, 2017)(Sugilar, 2013).

Ennis, Baron and Sternberg defines critical thinking as reflective thinking that is grounded and focused on establishing what to believe or what to do, while Langrehr stated that critical thinking is evaluative thinking involving the relevant criteria in accessing information along with accuracy, relevance, confidence, constancy, and bias(Sumarmo, 2015).Another opinion, Glaser (Permana \& Sumarmo, 2007) states that Mathematical critical thinking contains abilities and dispositions combined with knowledge, mathematical reasoning abilities, and cognitive strategies that were previously used to generalize, prove, assess reflective mathematical situations'. In line with that, (Men, 2017) argues that critical thinking is reasonable and reflective thinking that is carried out systematically on all information or problems obtained so that it can make the right decisions. The purpose of critical thinking is to achieve deep understanding. Perkins and Murphy 2006 identified a critical thinking model consisting of four stages, namely clarification, assessment, inference and strategy. Whereas according to(Ennis, 2000) Indicators of critical thinking skills are: (a) Providing simple explanations (elemntary clarification), (b) Building basic skills (basic support), (c) Making conclusions (inference), (d) Making further explanations (advance clarification), (e) Determine strategies and tactics to solve problems.

Kilpatrick, Swafford and Finder suggest mathematical dispositions are positive attitudes and habits of seeing mathematics as logical and useful. Bandura added that mathematical dispositions involve three interrelated processes, namely self-observation, self-evaluation and self-reaction. These three processes are part of metacognition of goal setting in mathematical dispositions(Hendriana, Rohaeti, \& Sumarmo, 2017).

(Sugilar, 2013) Mathematical disposition is one of the factors supporting the success of student mathematics learning. Students need a mathematical disposition to survive in the face of problems, take responsibility and familiarize good work in mathematics, attitude and good thinking habits in essence will form and foster mathematical dispositions. 
114 Nurbaeti, Sugiharti \& Maya. Improving Critical Thinking Ability and Mathematical Disposition of High School Students Through Integrated Saintific Approach to Brain Baseed Learning

Sumarmo (Lestari \& Yudhanegara, 2017) argues that mathematical dispositions are desires, awareness, tendencies, and strong dedication to students to think and do mathematically. Polking (Sumarmo, 2015) suggests indicators of mathematical disposition, namely: 1) confidence in using mathematics, solving problems, giving reasons and communicating ideas, 2) flexibility in investigating mathematical ideas and trying to find alternative methods in solving problems, 3) diligently working on mathematical assignments 4) interest, curiosity and meeting power in performing mathematical tasks, 5) tend to monitor, reflect on their own performance and reasoning, 6) assess the application of mathematics to other situations in mathematics and everyday experience, 7) appreciation of the role of mathematics in value culture, mathematics as a tool and as a language.

Based on the description above, a learning approach is needed that can optimize students 'ability to improve their critical and creative thinking skills and foster students' mathematical dispositions. Learning approaches that match the characteristics of these students are approaches Scientific Brain-based learning integration, the reason researchers try to contribute to a scientific approach that must be applied in schools with regard to school curriculum rules that require using a scientific approach, this approach is integrated with brain-based learning that is aligned with students' abilities in dealing with mathematical problems.

Scientific approaches include component 1) observing, 2) questioning, 3) associating, 4) experimenting, 5) networking) (Rudyanto, 2014). In line with that (Sariningsih \& Kadarisma, 2016) suggests scientific learning is learning that adopts scientific steps in building knowledge through scientific methods. In the learning process touches three domains, namely attitudes, knowledge and skills.

The scientific approach makes learning more active and not boring. Students can construct their knowledge and skills through the facts found in investigations in the field for learning. In mathematics learning for example, students can be invited to see events directly, observe events, phenomena (Wibowo, 2017).

The scientific approach that is integrated with brain based learning is according to (Abdurrahman \& Sintawati, 2013)(Lestari, 2014) Brain Based Learning is an alternative learning strategy that can be used by teachers to develop students' critical and creative thinking skills, because Brain-Based Learning is a strategy that facilitates learning activities that involve the power of both hemispheres.

According to Gulpinar (Nahdi, 2015) what distinguishes BBL from other learning models is that BBL has the characteristics of relaxed learning, constructive learning, learning that emphasizes inter-student collaboration, there is enough time for students to reflect on the material they have received, meaningful and contextual learning.

The Scientific approach to integrating brain based learning is a learning approach whose implementation process is based on the steps of the scientific approach but is integrated with activities in brain based learning where the results are expected to make learning meaningful so as to improve critical and creative thinking skills and mathematical dispositions. 


\section{METHOD}

This study was an experimental design pretest-posttest aimed at analyzing the role of the brain based learning integrated approach to the criticaL thinking ability and mathematical disposition of students. This study involved 72 eleventh grade students, mathematical critical thinking tests, mathematical disposition scales. The mathematical critical thinking ability test consisted of 4 items, and by using(Hendriana et al., 2017), and (Sumarmo, 2015) as references it was obtained charactristic CTS test as follow: reliability test was $r=.77$; item validity were $.54 \leq \mathrm{IV} \leq .83$; discriminat power were $.22 \leq \mathrm{DP} \leq .49$, and difficulty index were $.21 \leq \mathrm{DI} \leq$ .62 . While MD scale contained 30 items, reliabilty of MD was .87 , and item validity were .33 $\leq \mathrm{IV} \leq .66$; perception on SAIBBL scale contained 22 items, reliability scale was .94 , item validity $.35 \leq \mathrm{IV} \leq .86$; In the following, we attached sample items of mathematical critical thinking test, sample of mathematical disposition scale, and sample of perception on SAIBBL scale.

\section{Sample 1. Item of mathematical critical thinking test}

ability indicator : Provide a simple explanation related to the arithmetic sequence

A company in the first year produced 5,000 units of goods. In the following years, production fell by 80 units per year.

Determine the number of years in which the company produces 3,000 units of goods and explain the reasons underlying your answer!

\section{Sample 2. Item of mathematical critical thinking test}

ability indicator : Develop strategies and tactics to solve problems in geometric series A ball is dropped on the floor. The first reflection was as high as $9 \mathrm{~m}$, the second reflection was as high as $3 \mathrm{~m}$, the third reflection was as high as $1 \mathrm{~m}$, and so on with the ball fixed.

Develop a strategy for calculating the reflection height of the ball after bouncing 6 times and finishing!

\section{Sample 3. Item of Mathematical Disposition Scale}

Table 1. Grains of Test Items Mathematical Disposition Scale

\begin{tabular}{|c|c|c|c|}
\hline & & \multicolumn{2}{|c|}{ Statement Form } \\
\hline Indicator & Activity / Feeling / Opinion & $(+)$ & $(-)$ \\
\hline \multirow[t]{2}{*}{ Confident } & $\begin{array}{l}\text { I was pessimistic about learning mathematics } \\
\text { about sequences and sequences }\end{array}$ & & $\sqrt{ }$ \\
\hline & $\begin{array}{l}\text { I am sure I can solve the sequence and sequence } \\
\text { questions correctly }\end{array}$ & $\sqrt{ }$ & \\
\hline \multirow[t]{2}{*}{ Flexibility } & $\begin{array}{l}\text { I work on math problems using one method that I } \\
\text { really understand }\end{array}$ & & $\sqrt{ }$ \\
\hline & $\begin{array}{l}\text { I wrote new ways that my friends found to increase } \\
\text { my knowledge }\end{array}$ & $\sqrt{ }$ & \\
\hline
\end{tabular}


116 Nurbaeti, Sugiharti \& Maya. Improving Critical Thinking Ability and Mathematical Disposition of High School Students Through Integrated Saintific Approach to Brain Baseed Learning

Table 2. Item of Perception on SAIBBL Scale

\begin{tabular}{cllll}
\hline No. & \multicolumn{1}{c}{ Statement } & SA & D & SD \\
\hline 1. & $\begin{array}{l}\text { Mathematics problem on student work sheet } \\
\text { insufficient with prior student's knowledge. }\end{array}$ & & & \\
\hline 2. & $\begin{array}{l}\text { Mathematics task on student's work sheet } \\
\text { reqiured student to solve it accurately. }\end{array}$ & & \\
\hline 3. & $\begin{array}{l}\text { This new learning approach motivate student to } \\
\text { solve mathematics problem by various strategies. }\end{array}$ & & \\
\hline 4. & $\begin{array}{l}\text { Student was afraid for presenting work-group } \\
\text { solution in front of the class. }\end{array}$ \\
\hline 5. & $\begin{array}{l}\text { Learning process in this new teaching approach } \\
\text { caused students less appreciate the beauty of } \\
\text { mathematics rules and principles. }\end{array}$ & \\
\hline 6 & $\begin{array}{l}\text { Mathematics task in student's work sheet allow } \\
\text { student to solve by own strategy }\end{array}$ & \\
\hline
\end{tabular}

\section{RESULTS AND DISCUSSION}

Description of CTS, MD and perception toward SAIBBL of students is attached in Table 1. From Table 3., in pre-test it found that there was no difference of CTS of students in both teaching approaches, and the grades were at very low level $(20.39 \%$ and $18.77 \%$ out of ideal score). Nevertheles, after learning process, on ( (Abdurrahman \& Sintawati, 2013) (Rudyanto, 2014) (Lestari, 2014) (Sariningsih \& Kadarisma, 2016) (Wibowo, 2017) ) CTS and its gain $(\mathrm{N}<\mathrm{G}>)$, students taught by SAIBBL attained better grades $(45.16 \%$ out of ideal score, $\mathrm{N}<\mathrm{G}>.29$ ) than the grades of students taught by conventional teaching (35.22\% out of ideal score, $\mathrm{N}<\mathrm{G}>.18$ ). The findings on CTS of this study are similar to the previous studies, that students taught by SAIBB; obtain better grades than students taught by conventional teaching.

Table 3. Description of Mathematical Critical Thinking Ability, Mathematical Disposition And Perception on SAIBBL

\begin{tabular}{|c|c|c|c|c|c|c|c|c|c|}
\hline \multirow[b]{2}{*}{ Variables } & \multirow{2}{*}{$\begin{array}{c}\text { Sta } \\
\mathrm{t}\end{array}$} & \multicolumn{4}{|c|}{ SAIBBL } & \multicolumn{4}{|c|}{ SA } \\
\hline & & $\begin{array}{l}\text { Pre- } \\
\text { Test }\end{array}$ & $\begin{array}{c}\text { Post- } \\
\text { Test }\end{array}$ & $\begin{array}{c}\mathrm{N} \\
\text { Gain } \\
\end{array}$ & $\mathrm{n}$ & $\begin{array}{l}\text { Pre- } \\
\text { Test }\end{array}$ & $\begin{array}{c}\text { Post- } \\
\text { Test }\end{array}$ & N Gain & $\mathrm{N}$ \\
\hline \multirow{3}{*}{ CTS } & $\bar{X}$ & $\begin{array}{l}11.0 \\
8\end{array}$ & 26.65 & .29 & \multirow{3}{*}{36} & 12.03 & 20.78 & .18 & \multirow{3}{*}{36} \\
\hline & $\%$ & $\begin{array}{l}18.7 \\
7\end{array}$ & 45.16 & & & 20.39 & 35.22 & & \\
\hline & $\mathrm{S}$ & 3.17 & 3.18 & .08 & & 3.83 & 4.36 & .09 & \\
\hline \multirow{4}{*}{ MD } & $\bar{X}$ & & 73.43 & & \multirow{3}{*}{36} & & 77.96 & & \multirow{4}{*}{36} \\
\hline & $\%$ & & 60.18 & & & & 63.90 & & \\
\hline & $\mathrm{S}$ & & 10.97 & & & & 7.76 & & \\
\hline & $\bar{X}$ & & $\begin{array}{l}69.65 \\
7256\end{array}$ & - & 36 & & & & \\
\hline
\end{tabular}

Note:

CTS : Ideal score: 59 MD : Ideal score: $122 \quad$ SAIBBL : Ideal score: 96 
But, in this study students' grades on mathematical critical thinking ability are at low level. Moreover, on MD there is no difference student's grades in both teaching approaches, and those grades were at medium level. The testing hypothesis of those data was attached in Tabel 2 .

Table 4. Testing Hypothesis of Mean Difference of Mathematical Critical Thinking Skill, and Mathematical Disposition on Both Teaching Approaches

\begin{tabular}{|c|c|c|c|c|c|c|c|}
\hline Variables & $\begin{array}{l}\text { Teaching } \\
\text { Approach }\end{array}$ & $\bar{x}$ & SD & $\mathrm{N}$ & $\begin{array}{l}\text { Sig } \\
(2- \\
\text { tailed) }\end{array}$ & $\begin{array}{l}\operatorname{Sig}(1- \\
\text { tailed). }\end{array}$ & Interpretation \\
\hline \multirow[b]{2}{*}{ CTS } & SAIBBL & 26.65 & 3.18 & 36 & \multirow[t]{2}{*}{.000} & \multirow[t]{2}{*}{$.000<.05$} & $\mathrm{CTS}_{\mathrm{SAIBBL}}>$ \\
\hline & SAI & 11.08 & 3.17 & 36 & & & CTS SAI \\
\hline \multirow{2}{*}{$\begin{array}{c}\text { N-Gain } \\
\text { CTS }\end{array}$} & SAIBBL & .29 & .08 & 36 & \multirow[t]{2}{*}{.000} & \multirow[t]{2}{*}{$.000<.05$} & N-Gain CTS SAIBBL $^{>}$ \\
\hline & SAI & .18 & .09 & 36 & & & N-Gain CTS SAI $_{\text {I }}$ \\
\hline \multirow[b]{2}{*}{ MD } & SAIBBL & 73.43 & 10.96 & 36 & \multirow[t]{2}{*}{.617} & \multirow[t]{2}{*}{$.308>.05$} & No difference of \\
\hline & SAI & 77.96 & 7.76 & 36 & & & $\mathrm{MD}_{\mathrm{SAIBBL}}$ and $\mathrm{MD}_{\mathrm{SAI}}$ \\
\hline
\end{tabular}

Note: CTS Ideal score: 59

Ideal score MD :122

Concerning perception on SAIBBL, the study found students' opinion is at fairly good level $(72,56 \%$ out of ideal score). These findings are similar to (Rudyanto, 2014) findings. Some student difficulties in completing Critical mathematical thinking tasks are illustrated in Table 4. The study found that students received treatment with SAIBBL, achieving low scores (less than $60 \%$ of ideal scores) on two items of the CTS test. In fact, students who received treatment with SAI were aware of the difficulties in all CTS test questions. Apparently, CTS problems are a very difficult task for most high school students.

Table 5. Mean Score of Each Item of CTS Test of Students In Both Teaching Approaches

\begin{tabular}{lccccccc}
\hline Teaching & Stat.Desc & No.1 & No 2. & No.3 & No.4 & No.5 & Entirely \\
\cline { 2 - 8 } Approach & Ideal score & 8 & 12 & 15 & 12 & 12 & 59 \\
\hline \multirow{2}{*}{ SAIBBL } & $\overline{\mathrm{X}}$ & 5.12 & 8.21 & 7.22 & 3.54 & 2.92 & 27.01 \\
\cline { 2 - 8 } & $\%$ of IS & 64.00 & 45.62 & 48.13 & 29.50 & 24.33 & 45.78 \\
\hline \multirow{2}{*}{ SAI } & $\overline{\mathrm{X}}$ & 2.32 & 5.16 & 2.56 & 2.89 & 7.67 & 20.60 \\
\cline { 2 - 8 } & $\%$ of IS & 29.00 & 43.00 & 17.06 & 24.08 & 64.00 & 34.91 \\
\hline
\end{tabular}

Further analysis, is concerning association between CTS and MD. That association is analyzed by using contigency table such as in Table 4 and by using $\chi^{2}$ testing. The analysis obtain value $\chi^{2}=4,368 \mathrm{a}$ and sig. $(2$ tailed-.113 $>.005)$. This is meant that there is no association between CTS and MD.

Table 6. Contigency Table of CTS and MD in SAIBBL

Class

\begin{tabular}{ccccc}
$\begin{array}{c}\text { MSE } \\
\text { MCTA }\end{array}$ & High & Medium & Low & Total \\
\hline Medium & 1 & 0 & 0 & 1 \\
\hline
\end{tabular}


118 Nurbaeti, Sugiharti \& Maya. Improving Critical Thinking Ability and Mathematical Disposition of High School Students Through Integrated Saintific Approach to Brain Baseed Learning

\begin{tabular}{ccccc}
\hline Low & 4 & 8 & 13 & 25 \\
\hline Total & 5 & 8 & 13 & 26 \\
\hline
\end{tabular}

Besides that, the students' grade on MD is at medium level. This finding is in line with (Abdurrahman \& Sintawati, 2013) that MD or other affective behavior cannot be taught directly such as taught a certain mathematical content. Improving better MD or other soft-skill in mathematics need a long period of time, and through four ways namely: Be sure student to understand the meaning of mathematical disposition and the important of owning MD attitudes in learning; Teacher should performed behavior that wished in mathematical MD attitudes; Familiarize students to behave the wished in MD attitudes; Carry out integrated and continous mathematics teaching-learning process.

Besides those findings, this study also find that students perform more active learning during SAIBBL compare to students during conventional teaching. At the first lesson, actualy students still confuse to learn mathematical task on students work sheet (Figure 1).

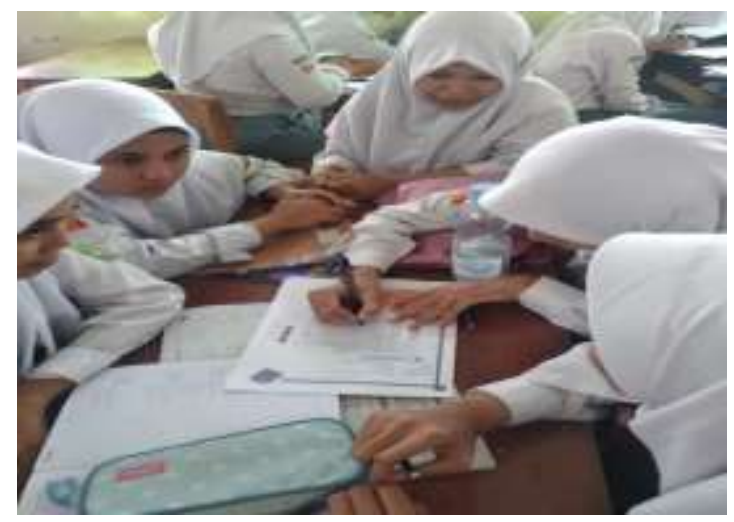

Figure 1. the learning process uses the scientific approach to integrating brain based learning

Eventhough, on further lessons students accustomed to work passionately in small group discussion, to ask to teacher, and to present their work in front of the class (Figure 2). While, in the conventional teaching student less active learning and they more paid attention on teacher's explantion.

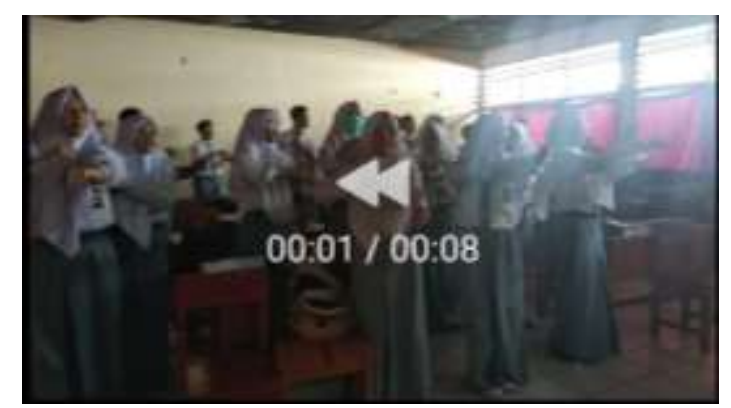

Figure 2. brain gym activities that are part of bra integrity integrity learning activities.

Student's perception on SAIBBL is accquired through limited interview to some selected students representation of high group, medium group, and low group students as well. 
Entirely, students peformed positive opnion on SAIBBL. High group and medium group students proposed that problems on student work sheet difficult indeed, but they are challenging, relates to daily life problem and can be applied in other dicipline; learning material help students to learn earlier; discussion atmosphere some time is tighten but it can be overcomed through working together. Low group students express that problems on student work sheet are difficult, can't be imagined, and sometimes can't be understood; but student work sheet and learning material help students to learn, SAIBBL is worthwhile in daily life, and learning in smal group is better than learning individually. Those positive students' opinion on SAIBBL was similar to the findings of (Lestari, 2014) which report students performed positive opnion on SAIBBL

\section{CONCLUSION}

Based on the findings and discussion, this research concludes as follows. SAIBBL takes a better role than SAI about student CTS and its benefits, but not at MD students. However, CTS students are still at a low level and at MD grades students at the middle level. Treatment of students on both approaches to realize the difficulties in solving problems of mathematical critical thinking skills.

Another conclusion is that, students form positive opinions about SAIBBL and they show active learning in the five phases of the SAIBBL phase. In addition, there is no relationship between CTS ability and MD

\section{ACKNOWLEDGMENTS}

The researcher thanked all parties involved in this research, especially to the headmaster of SMA 2 Karawang who had given permission to the researchers to take action on students who were used as research samples and supervisors who always direct, support, and assist during the research process from beginning to end.

\section{REFERENCES}

Abdurrahman, G., \& Sintawati, M. (2013). Strategi Brain-Based Learning dalam Pembelajaran Matematika. Seminar Nasional Matematika dan Aplikasinya 2013.

Ennis, R. . (2000). Book reviews. (1996), 48-51.

Hendriana, H., Rohaeti, E.., \& Sumarmo, U. (2017). Hard Skill dan Soft Skill Matematik Siswa (N. . ATIF, ed.). Bandung: Refika Aditama.

Lestari, K. E. K. A. (2014). Issn 2338-2996. Jurnal Pendidikan UNSIKA, 2(November 2014), $36-46$.

Lestari, K. E. K. A., \& Yudhanegara, M. (2017). Penelitian Pendidikan Matematika.

Men, E. (2017). Ju r n a $1 \mathrm{M}$ a t e m a t i k a K r e a t i f -I n o v a t i f. Kreano, 8(2), 191-198. https://doi.org/10.15294/kreano.v8i2.7192

Nahdi, D. S. (2015). Meningkatkan Kemampuan Berpikir Kritis dan Penalaran Matematis Siswa melalui Model Brain Based Learning. Jurnal Cakrawala P, I(1), 13-22.

Nurjaman, A., \& Sari, I. P. (2017). The Effect of Problem Posing Approach Towards Students' Mathematical Disposition, Critical \& Amp; Creative Thinking Ability Based on School Level. In Infinity Journal. https://doi.org/10.22460/infinity.v6i1.223

Permana, Y., \& Sumarmo, U. (2007). Mengembangkan Kemampuan Penalaran dan Koneksi Matematik Siwa SMA Melalui Pembelajaran Berbasis Masalah. Jurnal Educationist, I(2), 116-123.

Rudyanto, H. . (2014). Model Discovery Learning dengan Pendekatan Saintifik Bermuatan 
120 Nurbaeti, Sugiharti \& Maya. Improving Critical Thinking Ability and Mathematical Disposition of High School Students Through Integrated Saintific Approach to Brain Baseed Learning

Karakter untuk Meningkatkan Kemampuan Berpikir Kreatif. PREMIERE EDUCANDUM, 4(1), 41-48.

Sariningsih, R., \& Kadarisma, G. (2016). Meningkatkan Kemampuan Berpikir Kreatif Matematis dan Kemandirian Belajar Siswa SMP melalui Pendekatan Saintifik Berbasis Etnomatematika. 3(1), 53-56.

Senjayawati, E. (2018). Peningkatan Kemampuan Berpikir Kritis Matematik. EDU-MAT Jurnal Pendidikan Matematika, 4(1), 58-64.

Sugilar, H. (2013). Meningkatkan kemampuan berpikir kreatif dan disposisi matematik siswa madrasah tsanawiyah melalui pembelajaran generatif. Infinity, 2(2), 156-168.

Sumarmo, U. (2015). Kumpulan Makalah Berpikir dan Disposisi Matematika serta Pembelajaran.

Wibowo, A. (2017). Pengaruh Pendekatan Pembelajaran Matematika Realistik dan Saintifik terhadap Prestasi Belajar, Kemampuan Penalaran Matematis dan Minat Belajar. Jurnal Riset Pendidikan Matematika How to Cite Jurnal Riset Pendidikan Matematika, 4(1), 110. 